\title{
Penggunaan Metode Demonstrasi untuk Meningkatkan Prestasi Belajar Siswa dalam Mata Pelajaran Seni Budaya Materi Pokok Lagu-Lagu Daerah
}

\author{
The Use of Demonstration Methods to Increase Students' Learning \\ Achievement in the Main Subjects of Cultural Arts in Regional Songs
}

\author{
Dina Aryani \\ SMPN 34 Bandung, Bandung, Jawa Barat, Indonesia \\ dinaaryani217@gmail.com
}

Naskah diterima tanggal 07/06/2019, direvisi akhir tanggal 04/07/2019, disetujui tanggal 31/07/2019

\begin{abstract}
Abstrak
Tujuan dari penelitian ini adalah untuk meningkatkan prestasi belajar siswa melalui metode demonstrasi pada siswa SMP. Penelitian ini menggunakan penelitian tindakan kelas (PTK) dengan metode demonstrasi. Partisipan penelitiannya adalah guru dan siswa SMP. Penelitian ini dilakukan selama Juli-Agustus 2018 dalam tiga siklus. Hasil siklus pencapaian pertama, nilai rata-rata harian tertinggi adalah 85 , terendah 25 dan rata-rata 58,12, jumlah siswa yang mengalami penguasaan pembelajaran adalah 7 orang $(21,87 \%)$. Prestasi siklus 2 , nilai rata-rata harian tertinggi adalah 100 , terendah 40 , dan rata-rata 74,53 jumlah siswa yang mengalami penguasaan belajar adalah 15 orang $(46,87 \%)$. Hasil siklus ke tiga pencapaian, nilai rata-rata tertinggi 100, terendah 60 dan rata-rata adalah 83,75 jumlah siswa yang mengalami penguasaan belajar sebanyak 22 orang $(68,75 \%)$. Dengan demikian tindakan III menyimpulkan pembelajaran dengan Metode Demonstrasi, karena nilai tes rata-rata dan nilai serap klasik siswa di atas 65 dan KKM di atas 75 sudah di atas 85\%. Penggunaan metode demonstrasi terbukti mampu meningkatkan kemampuan dan prestasi belajar siswa dalam pembelajaran Seni Budaya dalam Materi Utama Lagu Daerah.
\end{abstract}

Kata kunci: Metode Demonstrasi, Prestasi Belajar Siswa

\begin{abstract}
The objective of this study was to increase students'learning achievement through demonstration method of students in secondary school. This study was categorized into classroom action research. The participants of the study were the teacher and the students. The actions were conducted during July-August 2018 in three cycle. The results of the first cycle of achievement, the highest daily average value was 85, the lowest was 25 and the average was 58.12, the number of students who experienced mastery learning was 7 people (21.87\%). In cycle 2, the highest daily average value is 100, the lowest is 40, and the average is 74.53 the number of students who experience mastery learning is 15 people (46.87\%). The results of the third cycle of achievement, the highest average value of 100, the lowest 60 and the average is 83.75 the number of students who experience mastery learning as many as 22 people (68.75\%). Thus this action III concludes learning with the Demonstration Method, because the average test score and classical absorptive value of students above 65 and KKM above 75 already are above 85\%. The use of demonstration method proved to be able to improve the ability and learning achievement of class VIII C students of SMPN 34 Bandung in learning Cultural Arts in the Main Material of Regional Songs.
\end{abstract}

Keywords: Demonstration Method, Students'Learning Achievement. 


\section{PENDAHULUAN}

Seni Budaya merupakan salah satu mata pelajaran yang terdapat pada program pendidikan dasar dan menengah yang mengacu pada Kurikulum Berbasis Kompetensi (KBK), kemudian disempurnakan lagi dalam Kurikulum Tingkat Satuan Pendidikan (KTSP) dan terakhir kurikulum K13. Kurikulum Pendidikan Nasional (1993-1994:86) mata pelajaran pendidikan seni budaya, bertujuan untuk menanamkan dan mengembangkan cita rasa keindahan. Pemerintah Indonesia senantiasa berkontribusi terhadap perkembangan Mata Pelajaran Seni Budaya.

Rumusan tujuan pendidikan nasional dalam Undang-undang Nomor 20 Tahun 2003 tentang Sistem Pendidikan Nasional menyatakan bahwa:

"Pendidikan nasional berfungsi untuk mengembangkan kemampuan dan membentuk watak serta peradaban bangsa yang bermartabat dalam rangka mencerdaskan kehidupan bangsa, bertujuan untuk mengembangkan potensi peserta didik agar menjadi manusia yang beriman dan bertakwa kepada Tuhan Yang Maha Esa, berakhlak mulia, sehat, berilmu, cakap, kreatif, mandiri dan menjadi warga negara yang demokratis serta bertanggung jawab".

Selama ini pendidikan hanya tampak dari kemampuan siswa menghafal fakta-fakta walaupun banyak siswa mampu menyajikan tingkat hafalan yang baik terhadap materi yang diterimanya, tetapi pada kenyataannya mereka seringkali tidak memahami secara mendalam subtansi materinya. Dampaknya, sebagian besar dari siswa tidak mampu menghubungkan antara apa yang mereka pelajari dengan bagaimana pengetahuan tersebut akan dimanfaatkan. Mereka sangat perlu untuk memahami konsep-konsep yang berhubungan dengan tempat tinggal dan masyarakat pada umumnya di mana mereka akan hidup. Siswa memiliki kesulitan memahami konsep akademik sebagaimana mereka biasa diajarkan, yaitu menggunakan sesuatu yang abstrak dan metode ceramah.

Adapun tujuan pembelajaran yang diharapkan dapat tercapai Seni Budaya melalui proses pembelajaran yang berdasarkan pada kurikulum 2004 adalah melatih cara berfikir dan bernalar, mengembangkan aktifitas kreatif, mengembangkan kemampuan memecahkan masalah, mengembangkan kemampuan menyampaikan Seni Budaya melalui informasi atau mengkomunikasikan gagasan. Sedangkan salah satu prinsip pengembangan dalam kurikulum 2013 adalah prinsip berpusat pada anak. Dipandang dari tujuan pembelajaran secara prinsip pengembangan kurikulum 2013 tersebut, maka metode pembelajaran demonstrasi merupakan salah satu model pembelajaran Seni Budaya yang sesuai dengan kurikulum 2013.

Saat ini yang seharusnya dilakukan oleh para guru Pendidikan Seni Budaya adalah mengembangkan model pembelajaran yang dapat meningkatkan kompetensi peserta didik baik dalam pemahaman mengenai materi pelajaran, mendorong mereka untuk mengamalkannya dan sekaligus dapat membentuk akhlak dan kepribadiannya. Belajar akan lebih bermakna jika anak mengalami apa yang dipelajarinya, bukan mengetahuinya. Pembelajaran yang berorientasi terget penguasaan materi terbukti berhasil dalam kompetisi mengingat dalam jangka pendek, tetapi gagal dalam membekali anak memecahkan masalah dalam kehidupan jangka panjang. Pendekatan Demonstrasi merupakan konsep belajar yang membantu guru mengaitkan antara materi yang diajarkannya dengan situasi dunia nyata siswa dan mendorong siswa membuat hubungan antara pengetahuan yang dimilikinya dengan penerapannya dalam kehidupan mereka sebagai anggota keluarga dan masyarakat.

Pendidikan Seni Budaya sebagai rumpun pelajaran mulai dari tingkat dasar sampai dengan perguruan tinggi yang sarat dengan nilai-nilai budaya, nilai-nilai dan aktualisasi diri dalam kehidupan sehari-hari, sudah barang tentu menuntut adanya sejumlah kompetensi yang harus dimiliki siswa, sesuai dengan tuntutan kurikulum 2013, kompetensi yang harus dimiliki siswa mencakup tiga hal yaitu: 1) kompetensi kognitif; 2) afektif; dan 3) psikomotor. Gabungan dari tiga jenis kompetensi itu yang akan melahirkan life skills (keterampilan hidup).

$$
\text { Metode demonstrasi adalah }
$$

cara penyajian bahan pelajaran dengan 
memperagakan atau mempertunjukkan kepada peserta didik suatu proses, situasi atau benda tertentu yang sedang dipelajari baik sebenarnya atau tiruan yang sering disertai penjelasan lisan. Metode demonstrasi dikatakan sebagai sebuah cara penyajian pelajaran dengan memperagakan atau mempertunjukkan kepada peserta didik suatu proses, situasi atau benda tertentu yang sedang dipelajari baik dalam bentuk sebenarnya maupun dalam bentuk tiruan yang dipertunjukkan oleh guru atau sumber belajar lain yang ahli dalam topik bahasan (Sumantri \& Permana, 2001:82 ).

Menurut Suaedy (2011) metode demonstrasi adalah suatu cara penyampaian materi dengan memperagakan suatu proses atau kegiatan. Sedangkan menurut Muhibbin (2000:208) metode demonstrasi adalah metode mengajar dengan cara memperagakan barang, kejadian, aturan dan urutan melakukan kegiatan, baik secara langsung maupun melalui penggunaan media pengajaran yang relevan dengan pokok bahasan atau materi yang sedang disajikan.

Fathurrohman (2007:98) mengemukakan bahwa tujuan penerapan metode demonstrasi adalah untuk memperjelas pengertian konsep dan memperlihatkan cara melakukan sesuatu atau proses terjadinya sesuatu seperti: a). Mengajar siswa tentang suatu tindakan, proses atau prosedur keterampilan-keterampilan fisik dan motorik; b). Mengembangkan kemampuan pengamatan pendengaran dan penglihatan para siswa secara Bersama-sama; c). Mengkonkritkan informasi yang disajikan kepada siswa.

Pembelajaran menggunakan metode demonstrasi, yaitu pembelajaran yang mengaktifkan peserta didik, sehingga dengan menggunakan metode demonstrasi banyak kelebihan yang akan diperoleh. Menurut Sagala (2006) beberapa kelebihan dan kekurangan metode demonstrasi yaitu: 1) perhatian murid dapat dipusatkan; 2) dapat membimbing siswa kearah berpikir yang sama; 3) ekonomis dalam jam pelajaran; 4) siswa lebih mendapatakan gambaran yang jelas dari hasil pengamatan; 5) persoalan yang menimbulkan pertanyaan dapat di perjelas pada saat proses demonstrasi
Menurut Hasibuan (2006:31) langkahlangkah metode pembelajaran demonstrasi adalah sebagai berikut: merumuskan dengan jelas kecakapan dan atau keterampilan apa yang diharapkan dicapai oleh siswa sesudah demonstrasi itu dilakukan.

Prestasi belajar adalah sebuah kalimat yang terdiri dari dua kata yaitu prestasi dan belajar. Antara kata prestasi dan belajar mempunyai arti yang berbeda. Oleh karena itu, sebelum pengertian prestasi belajar, ada baiknya pembahasan ini diarahkan pada masing-masing permasalahan terlebih dahulu untuk mendapatkan pemahaman lebih jauh mengenai makna kata prestasi dan belajar. Hal ini juga untuk memudahkan dalam memahami lebih mendalam tentang pengertian prestasi belajar itu sendiri. Prestasi adalah hasil dari suatu kegiatan yang telah dikerjakan, diciptakan baik secara individu maupun secara kelompok (Djamarah, 2004:19).

Dari pengertian yang dikemukakan tersebut di atas, jelas terlihat perbedaan pada kata-kata tertentu sebagai penekanan, namun intinya sama yaitu hasil yang dicapai dari suatu kegiatan. Untuk itu, dapat dipahami bahwa prestasi adalah hasil dari suatu kegiatan yang telah dikerjakan, diciptakan, yang menyenangkan hati, yang diperoleh dengan jalan keuletan kerja, baik secara individual maupun secara kelompok dalam bidang kegiatan tertentu. Menurut Slameto (2015:2) bahwa belajar adalah suatu proses usaha yang dilakukan seseorang untuk memperoleh suatu perubahan tingkah laku yang baru secara keseluruhan, sebagai hasil pengalamannya sendiri dalam interaksi dengan lingkungannya.

Dalam PP Mendiknas No 22, 2006:263 disebutkan bahwa Pendidikan Seni Budaya dan keterampilan diberikan di sekolah karena keunikannya, kebermaknaan, dan kebermanfaatan terhadap perkembangan peserta didik, yang terletak pada pemberian pengalaman estetik dalam bentuk kegiatan berekspresi / berkreasi melalui pendekatan "belajar dengan seni," "belajar melalui seni", dan "belajar tentang seni" peran ini tidak dapat diberikan oleh mata pelajaran lain. Pembelajaran Seni Budaya adalah kegiatan pembelajaran yang berusaha menggali 
potensi estetis siswa serta mempengaruhi siswa agar mempunyai nilai estetis sehingga dapat memperhalus budi pekerti karena dalam seni terdapat unsur- unsur keindahan , keteraturan, kedisiplinan dan dinamika.

Tujuan pembelajaran Seni Budaya di SMP memberikan pemahaman, pengetahuan, pengalaman juga kemampuan berkarya seni agar merekabisaberapresiasi terhadap budaya sendiri dan bisa menghargai orang lain yang pada akhirnya mereka bisa berperan aktif dalam kehidupan bermasyarakat, berbangsa dan bernegara. Seni mempunyai sifat unik dan memilki karakteristik tertentu yang tidak dimiliki oleh pelajaran yang lain maka proses pembelajaran seni idealnya menggunakan beberapa metode atau strategi mengajar yang disesuaikan dengan kebutuhan.

Pada umumnya, lagu daerah dikenal sebagai "lagu rakyat" karena lagu daerah sebagian besar ditularkan dari anggota keluarga, kerabat, dan lingkungan sekitar secara turun temurun. Lagu daerah lahir dan berkembang dari budaya dan tradisi masyarakat setempat.

Menurut Cahyanto (2009) Lagu daerah biasanya tidak diketahui penciptanya no name. Ada beberapa ciri khas lagu daerah, antara lain sebagai berikut; (1) Menceritakan tentang keadaan lingkungan ataupun budaya masyarakat setempat yang dipengaruhi oleh adat istiadat setempat; (2) Bersifat sederhana sehingga untuk mempelajarilagu daerah tidak dibutuhkan pengetahuan musik yang cukup mendalam seperti membaca dan menulis not balok; (3) Jarang diketahui pengarangnya; (4) Mengandung nilai-nilai kehidupan, unsur-unsur kebersamaan sosial, serta keserasian dengan lingkungan sekitar; (5) Sulit dinyanyikan oleh seseorang yang berasal dari daerah lain dan (6) Mengandung nilai-nilai keindahan yang unik dan khas.

Apresiasi musik menurut Cahyanto (2009:13) adalah suatu tingkat pencapaian daya tangkap dalam mendengarkan musik yang diiringi oleh sikap penuh penghayatan. Apresiasi dapat dicapai dengan dengan suatu usaha yang yata untuk dapat mendengarkan dengan seksama. Ada 4 cara dalam mendengarkan seksama dalam musik di antaranya sebagai berikut: (1) Mendengarkan musik dengan dinikmati. Pada tahap ini, pendengar benar-benar mempunyai perasaan enjoy dalam menikmati lantunan musik; (2) Mendengarkan Musik secara Emosional. Pada tahap ini, pendengar menyadari reaksi-reaksi emosional yang terbangkitkan oleh emosi; (3) Mendengarkan Musik secara Perspektif. Mendengarkan musik secara perspektif yaitu dengan mendengarkan musik dengan penuh konsentrasi dan kesadaran penuh tentang alunan musik yang didengarkan dan (4) Mendengarkan Musik secara Pasif. Mendengarkan musik secara pasif yaitu cara mendengarkan musik tidak secara dinikmati secara penuh ataupun dengan konsentrasi penuh. Menurut Cahyanto (2009:13) menyebutkan bahwa unsur-unsur dalam lagu daerah adalah irama, birama, nada, tangga nada dan tempo.

Tema penelitian mengenai
peningkatan belajar siswa melalui metode demontrasi telah banyak dibahas oleh penelitian-penelitian sebelumnya, diantaranya penelitian yang dilakukan oleh Basheer, Hugerat, Kortam, \& Hofstein (2017); Daluba (2013); Iline (2013); Kakak (2018); Nursidik (2016); Ocheje Ameh \& Dantani (2012); Puji (2012); Ramadhani \& Surya (2016); Rofi'ah Siti (2016); Sanawati, Rizal, \& Hasbi (2015); Sobon \& Lumowa (2018). Dengan banyaknya penelitian yang telah dilakukan membuktikan bahwa tema tersebut layak untuk diteliti karena masih menjadi perhatian peneliti dan untuk membuktikan apakah metode tersebut juga berlaku di Indonesia khususnya di SMP Negeri 34 Bandung.

\section{METODE PENELITIAN}

Penelitian ini dilaksanakan dengan tujuan untuk mengetahui dengan diterapkan Metode Demonstrasi pada mata pelajaran Seni Budaya dapat meningkatkan life skills siswa kelas VIII C SMP Negeri 34 Bandung. Melalui pembelajaran ini siswa dibawa ke dalam nuansa pembelajaran yang di dalamnya dapat memberi pengalaman yang berarti melalui proses pembelajaran yang berbasis masalah, penemuan (inquiry), 
independent learning, learning community, proses refleksi, permodelan sehingga dari proses tersebut diharapkan siswa dapat memahami konsep Seni Budaya.

Desain penelitian yang dipakai dalam penelitian ini adalah penelitian tindakan kelas yang dilaksanakan dalam beberapa siklus. Setiap siklus terdiri dari empat tahap yang mengacu pada model Kemmis dan MC Taggart. Ada perencanaan, tindakan, observasi dan refleksi. Peneliti melakukan penelitian di SMPN 34 Bandung yang terletak di jalan Waas Soekarno Hatta Bandung. Penelitian Tindakan Kelas ini dilaksanakan dalam setting pembelajaran Seni Budaya pada materi pokok lagu-lagu daerah dengan menggunakan metode demonstrasi pada siswa kelas VIII C di SMP Negeri 34 Bandung Bulan Juli sampai dengan Agustus 2018. Penggunaan metode demonstrasi dalam pembelajaran seni budaya pada materi pokok lagu-lagu daerah dalam penelitian konteks ini, didesain dalam siklus penelitian. Penelitian ini dirancang untuk kelas VIII C di mana terdapat 32 siswa. Instrumen yang digunakan penulis adalah obervasi, angket, butir soal tertulis dan studi dokumentasi.

Penelitian Tindakan Kelas dilakukan dengan beberapa langkah siklus, hingga tercapai tujuan yang diinginkan. Langkahlangkah penelitian terdiri atas empat komponen penelitian tindakan, yaitu perencanaan, tindakan, observasi, dan refleksi dalam suatu sistem spiral yang saling berkait. Selanjutnya pada siklus kedua dan seterusnya jenis penelitian tindakan yang dilakukan guru (peneliti), adalah memperbaiki rencana (revised plan), pelaksanaan (act), observasi (observe), dan refleksi (reflect). Demikian seterusnya, siklus akan terus berulang hingga pembelajaran dinilai berhasil, atau tergantung pada indikator keberhasilan program pembelajaran yang telah dirumuskan oleh guru (peneliti).

Secara operasional setting penelitian dalam konteks pembelajaran Seni Budaya pada materi pokok lagu-lagu daerah melalui penggunaan metode demonstrasi pada kelas VIII C di SMP Negeri 34 Bandung, dilaksanakan dalam empat tahapan sebagai berikut: (1) Perencanaan. Kegiatan perencanaan diawali dengan analisis perilaku belajar siswa kelas VIII dalam mengikuti pembelajaran seni budaya pada. pada materi pokok lagu-lagu daerah melalui penggunaan metode demonstrasi pada kelas VIII C di SMP Negeri 34 Bandung. Analisis perilaku belajar yang dilaksanakan oleh guru (peneliti), menggunakan hasil observasi kelas, telaah dokumen tentang hasil ulangan harian siswa pada mata pelajaran Seni Budaya di akhir dari hasil analisis perilaku belajar siswa tersebut, kemudian guru merencanakan tindakan yang akan dilakukan untuk memperbaiki mutu pembelajaran; (2) Pelaksanaan Tindakan. Pada tahap ini, guru melaksanakan pembelajaran dengan merujuk pada satuan pelajaran yang telah dirumuskan dalam tahap perencanaan. Pola pembelajaran yang dilaksanakan oleh guru (peneliti) dalam tindakan kelas ini mengikuti tahapan model demonstrasi; (3) Observasi. Kegiatan tahap observasi dilakukan oleh rekan kerja peneliti yang menjadi mitra dalam pelaksanaan Penelitian Tindakan Kelas ini. Adapun rekan mitra peneliti yang bertugas sebagi observer dan rekan diskusi dalam Penelitian Tindakan Kelas ini adalah sesama guru dalam rumpun mata pelajaran Seni Budaya. Profil guru yang menjadi mitra dalam penelitian ini, disajikan dalam lampiran. Tahap observasi dilaksanakan untuk meneliti hasil atau dampak dan siklus (tindakan) yang dilaksanakan terhadap obyek tindakan dalam penelitian ini yaitu meningkatnya pemahaman konsepsi siswa terhadap pembelajaran seni budaya pada materi pokok lagu-lagu daerah melalui penggunaan metode demonstrasi pada kelas VIII C di SMP Negeri 34 Bandung Tahun Pelajaran 2018/2019. Hasil observasi ini merupakan bahan pertimbangan untuk melakukan refleksi dan revisi terhadap tindakan yang telah dilakukan dan untuk menyusun rencana tindakan yang akan dilakukan dalam siklus selanjutnya; (4) Refleksi. Temuan pada waktu kegiatan siklus (tindakan pembelajaran dengan menggunakan Metode Demonstrasi pada kelas VIII C di SMP Negeri 34 Bandung yang diperoleh dari pelaksanaan pembelajaran dianalisis dari 
hasil diskusi antara guru (peneliti) dengan rekan mitra peneliti.

\section{HASIL DAN PEMBAHASAN}

\subsection{Hasil}

\section{Temuan Tindakan Pembelajaran Tindakan I}

Penelitian Tindakan Kelas ini, dilakukan dengan persiapan-persiapan yang sesuai dengan tahap-tahap penelitian. Persiapan yang dilakukan untuk melaksanakan tindakan I adalah penyusunan rencana pembelajaran tindakan I, lembar tugas siswa, pedoman observasi untuk mencatat proses pembelajaran yang dilakukan oleh peneliti atau guru dan siswa, soal untuk tes akhir disajikan juga dalam lampiran dan daftar kehadiran siswa pada tindakan I.

Nilai rata-rata harian tertinggi adalah 85 , terendah 25 dan rata-ratanya adalah 58.12 , jumlah siswa yang mengalami ketuntasan belajar sebanyak 7 orang $(21.87 \%)$. Dengan demikian hasil belajar siswa pada tindakan I perlu ditingkatkan pada tindakan selanjutnya (tindakan 2).

Refleksi dan Revisi Tindakan I. Berdasarkan Prestasi siklus I, pada umumnya nilai siswa kurang memuaskan dan masih banyak yang di bawah KKM, oleh karena itu perlu upaya perbaikan dan peningkatan hasil belajar siswa pada siklus 2, peneliti/guru kurang mengefektifkan dan mengevesienkan waktu pada saat pemasangan CD/DVD (inkuiri untuk topik) sampai menyita waktu hingga 15 menit, peneliti/guru tidak memberikan kesempatan kepada siswa untuk bertanya, penjelasan materi tentang apresiasi terhadap Lagu- Lagu Daerah dari guru cukup membosankan, dan pada saat kegiatan penutup, guru lupa memberikan penguatan terkait materi yang telah disajikan; namun langsung aja guru melakukan refleksi atau penilaian terhadap kegiatan yang sudah dilaksanakan.

\section{Temuan Tindakan Pembelajaran Tindakan II}

Penelitian Tindakan Kelas ini, dilakukan dengan persiapan-persiapan yang sesuai dengan tahap-tahap penelitian. Persiapan yang dilakukan untuk melaksanakan tindakan II sama dengan persiapan pada tindakan I, hanya pada tindakan II merupakan hasil perbaikan dan diskusi balikan dari tindakan I.

Nilai rata-rata harian tertinggi adalah 100 , terendah 40 , dan rata-ratanya adalah 74.53 jumlah siswa yang mengalami ketuntasan belajar sebanyak 15 orang (46.87\%). Dengan demikian hasil belajar siswa pada tindakan II perlu ditingkatkan pada tindakan selanjutnya (tindakan 3).

Refleksi dan Revisi Tindakan II: Ada peningkatan dibandingkan pada tindakan I, peneliti/guru telah mengefektifkan dan mengevesienkan waktu pada saat pemasangan CD/DVD (inkuiri untuk topik) hingga tidak menyita waktu, peneliti/guru telah memberikan kesempatan seluas-luasnya kepada siswa untuk bertanya, guru/peneliti telah memberikan penjelasan materi tentang apresiasi terhadap Lagu-Lagu Daerah dengan srtategi yang variatif dan menyenangkan, pada saat kegiatan penutup, guru/peneliti diharapkan memberikan penguatan terkait materi yang telah disajikan (konfirmasi).

\section{Temuan Tindakan Pembelajaran Tindakan III}

Persiapan yang dilakukan untuk melaksanakan tindakan 3 ini sama dengan persiapan tindakan 2 , hanya pada tindakan 3 merupakan hasil perbaikan dan diskusi balikan dari tindakan 2. Nilai rata-rata harian tertinggi adalah 100 , terendah 60 dan rataratanya adalah 83.75 jumlah siswa yang mengalami ketuntasan belajar sebanyak 22 orang $(68.75 \%)$. Dengan demikian tindakan III ini mengakhiri pembelajaran yang menggunakan Metode Demonstrasi, karena nilai rata-rata tes dan daya serap klasikal nilai siswa di atas 65 dan KKM di atas 75 sudah berada di atas $85 \%$.

Refleksi dan Revisi Tindakan III: Ada peningkatan dibandingkan pada tindakan II, peneliti/guru telah melaksanakan kegiatan pembelajaran secara optimal dengan menggunakan tahapan Metode Demonstrasi yaitu : Guru memberikan dorongan pemikiran kepada siswa bahwa akan belajar lebih bermakna dengan cara bekerja sendiri; dan mengkonstruksi sendiri pengetahuan dan keterampilan barunya; siswa melakukan kegiatan mendengarkan lagu dari CD/DVD (inkuiri untuk topik); guru memberikan kesempatan kepada siswa untuk bertanya; 
guru memberikan penjelasan materi ; guru membentuk kelompok siswa secara heterogen; guru menyuruh siswa dalam untuk mencari dan memecahkan masalah yang berkenaan dengan materi pokok;guru menyuruh perwakilan kelompok siswa untuk menjadi model sebagai contoh hasil penemuannya bersama kelompok belajar; siswa bersama guru melakukan refleksi di akhir pertemuan; guru memberikan penilaian yang sebenarnya dengan berbagai cara.

\subsection{Pembahasan}

Pengukuran keberhasilan pembelajaran dengan menggunakan Metode Demonstrasi, dilakukan analisis daya serap siswa kelas Kelas VIII C SMP Negeri 34 Bandung terhadap konsep ketuntasan hasil belajar (daya serap klasikal) untuk setiap tindakan.

1. Hasil prestasi siklus I, nilai rata-rata harian tertinggi adalah 85 , terendah 25 dan rata-ratanya adalah 58.12, jumlah siswa yang mengalami ketuntasan belajar sebanyak 7 orang $(21.87 \%)$.

2. Hasil prestasi siklus 2, nilai rata-rata harian tertinggi adalah 100, terendah 40, dan rata-ratanya adalah 74.53 jumlah siswa yang mengalami ketuntasan belajar sebanyak 15 orang ( $46.87 \%$ ). Dengan demikian hasil belajar siswa pada tindakan II perlu ditingkatkan pada tindakan selanjutnya (tindakan 3).

3. Hasil prestasi siklus 3, nilai rata-rata harian tertinggi adalah 100, terendah 60 dan rata-ratanya adalah 83.75 jumlah siswa yang mengalami ketuntasan belajar sebanyak 22 orang $(68.75 \%)$. Dengan demikian tindakan III ini mengakhiri pembelajaran yang menggunakan Metode Demonstrasi, karena nilai rata-rata tes dan daya serap klasikal nilai siswa di atas 65 dan KKM di atas 75 sudah berada di atas $85 \%$.

Berdasarkan daya serap rata-rata, maka pada tindakan 1 daya serap rata-rata sebagian besar ( 58.12), terjadi kenaikan pada tindakan II sebagian besar (74.53) dan tindakan 3 pada umumnya (83.75). Demikian juga dengan daya serap klasikal mengalami peningkatan, pada tindakan I sebagian kecil (21.87\%), pada tindakan 2 sebagian kecil
(46.87\%) dan pada tindakan 3 pada umumnya $(68.75 \%)$.

Hasil angket sikap siswa dijelaskan sebagai berikut. Angket ini digunakan untuk mengetahui sikap siswa terhadap pembelajaran Seni Budaya dengan menggunakan Metode Demonstrasi. Angket diedarkan pada siswa setelah selesai seluruh pelaksanaan pembelajaran tindakan. Pada angket yang diisi oleh siswa terdapat pernyataan-pernyataan mengenai indikator yang dapat mengukur kemampuan siswa pembelajaran Seni Budaya, baik sebelum maupun setelah menggunakan Metode Demonstrasi. Pernyataan angket di awal dan di akhir serupa, hanya saja ada perbedaan dalam penggunaan pendekatan yang diterapkan. Hal ini dapat dilihat pada lampiran Lembar angket berisi 10 pernyataan, para siswa yang belajar dengan menggunakan Metode Demonstrasi diminta pendapatnya mengenai penggunaan Metode Demonstrasi dalam pembelajaran Seni Budaya tersebut dengan menentukan salah satu pilihan ya atau tidak yang sesuai dengan sikapnya untuk pernyataan-pernyataan yang diajukan. Hasil angket siswa dianalaisis dengan menghitung banyaknya jenis sikap untuk setiap pernyataan.

Umumnya siswa yang setuju dengan pernyataan positif ada $83.45 \%$, artinya pada umumnya siswa menganggap bahwa penggunaan model Kontekstual mampu meningkatkan prestasi belajar siswa dalam pembelajaran Seni Budaya. Sedangkan untuk pernyataan negatif $11.40 \%$, artinya sebagian kecil siswa menyatakan bahwa penggunaan model Kontekstual membuat semakin tidak termotivasi dan kesulitan dalam mengisi tes akhir.

\section{KESIMPULAN}

Berdasarkan hasil Penelitian Tindakan Kelas ini prestasi belajar siswa yang dicapai setelah pembelajaran Seni Budaya dengan Metode Demonstrasi telah meningkat. Dalam pembelajaran dengan Metode Demonstrasi ini adalah model pembelajaran yang menitikberatkan kepada cara siswa dalam menghadapi masalah dan pemecahan masalahnya dilakukan secara kelompok 
dan langsung terjun ke materi pelajaran, hal tersebut akan menuntun siswa untuk hidup bermasyarakat. Adapun hasil yang didapat adalah: hasil prestasi siklus I, nilai rata-rata harian tertinggi adalah 85 , terendah 25 dan rata-ratanya adalah 58.12, jumlah siswa yang mengalami ketuntasan belajar sebanyak 7 orang $(21.87 \%)$. Hasil prestasi siklus 2 , nilai rata-rata harian tertinggi adalah 100 , terendah 40, dan rata-ratanya adalah 74.53 jumlah siswa yang mengalami ketuntasan belajar sebanyak 15 orang ( $46.87 \%)$. Dengan demikian hasil belajar siswa pada tindakan II perlu ditingkatkan. Hasil prestasi siklus 3 , nilai rata-rata harian tertinggi adalah 100 , terendah 60 dan rata-ratanya adalah 83.75 jumlah siswa yang mengalami ketuntasan belajar sebanyak 22 orang (68.75\%). Dengan demikian tindakan III ini mengakhiri pembelajaran yang menggunakan Metode Demonstrasi, karena nilai rata-rata tes dan daya serap klasikal nilai siswa di atas 65 dan KKM di atas 75 sudah berada di atas $85 \%$.

Berdasarkan hasil angket siswa di awal dan di akhir tindakan dengan menggunakan Metode Demonstrasi, terlihat bahwa setelah diterapkannya Metode Demonstrasi, ada perubahan sikap siswa kelas Kelas VIII C SMP Negeri 34 Bandung terhadap pembelajaran Seni Budaya, lalu bertambah dan meningkat jika dibandingkan sebelum menggunakan Metode Demonstrasi.

Penelitian Tindakan Kelas ini berakhir pada siklus ketiga karena semua persoalan yang muncul pada pembelajaran tersebut dapat teratasi secara optimal melalui penggunaan Metode Demonstrasi, dengan demikian penggunaan Metode Demonstrasi, telah terbukti mampu meningkatan prestasi belajar siswa tehadap pembelajaran LaguLagu Daerah di Kelas VIII C SMPN 34 Bandung tahun pelajaran 2018/2019.

\section{DAFTAR PUSTAKA}

Basheer, A., Hugerat, M., Kortam, N., \& Hofstein, A. (2017). The effectiveness of teachers' use of demonstrations for enhancing students' understanding of and attitudes to learning the oxidation-reduction concept. Eurasia Journal of Mathematics, Science and Technology Education, 13(3), 555-570. https://doi. org/10.12973/eurasia.2017.00632a

Cahyanto, M. B. (2009). Berlatih dan Berkreasi Musik 1. Jakarta: Tiga Serangkai.

Daluba, N. E. (2013). Effect of Demonstration Method of Teaching on Students' Achievement in Agricultural Science. World Journal of Education, 3(6), 1-7. https://doi.org/10.5430/wje.v3n6p1

Djamarah, S. B. (2004). Prestasi Belajar dan Kompetensi Guru. Surabaya: Usaha

Fathurrohman, P. (2007). Strategi Belajar Mengajar. Bandung: PT Refika Aditama.

Hasibuan, M. (2006). Proses Belajar Mengajar. Bandung: PT Remaja Rosdakarya.

Iline, C. S. (2013). Impacts of the Demonstration Method in the Teaching and Learning of Hearing Impaired Children. IOSR Journal Of Humanities And Social Science (IOSR-JHSS), 12(1), 48-54.

Kakak, D. (2018). PENGGUNAAN METODE DEMONSTRASI UNTUK MENINGKATKAN PRESTASI BELAJAR KONSEP PERUBAHAN BENDA PADA SISWA KELAS II. Jurnal Visi Ilmu Pendidikan, 1(1), 87-96. https://doi.org/10.26418/jvip.v10i1.25986

Muhibbin, S. (2000). Psikologi Pendidikan Dengan Pendekatan Baru. Bandung: PT Remaja Rosdakarya.

Nursidik, I. (2016). PENGGUNAAN Metode Demonstrasi Untuk Meningkatkan Hasil Belajar Pada Mata Pelajaran IPA Tentang Struktur Kerangka Tubuh Manusia (Penelitian Tindakan Kelas Pada Peserta Didik di Kelas 4 SD Negeri Bhakti Winaya Kecamatan Regol Kota Bandung). Universitas Pasundan.

Ocheje Ameh, P., \& Dantani, Y. S. (2012). Effects of Lecture and Demonstration Methods on the Academic Achievement of Students in Chemistry in Nassarawa Local Government Area of Kano State. International Journal of Modern Social Sciences Journal Homepage: Www.ModernScientificPress. Com, 1(1), 29-37.

gkatkan Prestasi Belajar IPA Siswa Kelas III Di MI Tarbiyatussibyan Boyolangu Tulungagung. Institut Agama Islam Negeri Tulungagung.

Ramadhani, N., \& Surya, E. (2016). Lecturer and Employee Performance Analysis in Department of Health Analyst, Health Polytechnic, Ministry of Health Makassar. International Journal of Sciences: Basic and Applied Research (IJSBAR), 34(2), 62-68.

Rofi'ah Siti. (2016). Penggunaan Metode Demonstrasi Dalam Meningkatkan Hasil Belajar Siswa Mata Pelajaran 
IPS Materi Dokumen Dan Benda Berharga Kelas II MI Gondoriyo, Bergas Kab. Semarang Tahun 2016/2017. Universitas Islam Negeri (UIN) Walisongo.

Sagala, S. (2006). Konsep dan makna Pembelajaran. Bandung: Alfabeta.

Sanawati, K., Rizal, M., \& Hasbi, M. (2015). Penerapan Metode Eksperimen Pada Mata Pelajaran IPA Untuk Meningkatkan Hasil Belajar Siswa Kelas V Di SDN 1 Rio Mukti. Jurnal Kreatif Tadulako, 5(2), 21-28.

Slameto. (2015). Belajar dan Faktor-Faktor Yang Mempengaruhinya. Bandung: Rineka Cipta.

Sobon, K., \& Lumowa, S. J. (2018). Penggunaan Metode Demonstrasi untuk Peningkatan Hasil Belajar Siswa Kelas V Pada Mata Pelajaran IPA di SD Negeri Kawangkoan Kecamatan Kalawat. Jurnal Pendidikan Dasar Nusantara, 3(2), 196-207.

Suaedy, S. (2011). Penerapan Berbagai Metode Pembelajaran dalam Kegiatan Diklat. http://bdksurabaya.kemenag. go.id

Sumantri, M., \& Permana, J. (2001). Strategi Belajar dan Mengajar. Bandung: CV Maulana. 